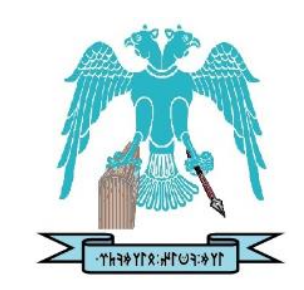

JOURNAL OF ENERGY SYSTEMS

$2021,5(3)$

\title{
Solar energy sector under the influence of Covid-19 pandemic: A critical review
}

Hasan Eroğlu (1)

Recep Tayyip Erdogan University, Department of Electrical and Electronics Engineering, Rize, Turkey, hasan.eroglu@erdogan.edu.tr

Erdem Cüce

Recep Tayyip Erdogan University, Department of Mechanical Engineering, Rize, Turkey, erdem.cuce@erdogan.edu.tr

Abstract: Different controversies arise when the world is dealing with the Covid-19 outbreak and fast solutions are produced in the field of health. However, the impact of Covid-19 on some critical sectors is perspicuous. One of the most important of those is the status of the solar industry, which is a favorite renewable and sustainable energy sector and the most sensitive part of global energy transformation. In this study, the solar energy sector has been examined in detail under the lens of Covid-19. The effect of the covid-19 outbreak on the sector has been tried to be measured and the steps that could be taken for a quick recovery have been proposed. In addition, the possible positive effects of the pandemic on the sector have been discussed within the perspective of the research.

Keywords: Covid-19, pandemic, solar energy sector

Cite this paper as:

Eroglu, H., Cüce, E., Solar energy sector under the influence of Covid-19 pandemic: A critical review. Journal of Energy Systems 2021; 5(3): 244-251, DOI: $10.30521 /$ jes. 942691

(c) 2021 Published by peer-reviewed open access scientific journal, JES at DergiPark (https://dergipark.org.tr/en/pub/jes) 


\section{INTRODUCTION}

Covid-19 pandemic, which cannot be prevented from spreading and whose treatment has not been found for all variants, yet causes undesirable effects in the world. In addition to the health problems, the epidemic, which has adverse environmental impacts $[1,2,3,4,5]$ and affects many sectors, also plays a key role in renewable and sustainable energy targets. The solar energy sector, which has particularly sensitive breaking points, is thought to be affected by the Covid-19 outbreak in the first degree $[2,6,7,8,9]$. However, the magnitude of the effect has not been fully revealed. In this context, detailed studies are needed on the effects of Covid-19 outbreak on the solar sector. Within the content of the research, which has a graphical representation shown in Fig. 1, the effects of Covid-19 pandemic on the solar industry have been extensively examined and the following important findings have been achieved:

-Because of the Covid-19 pandemic in the solar energy sector, the photovoltaic (PV) module prices have increased from 0.228 to $0.27 \$ / \mathrm{W}$.

-Firms adversely affected by the sector have been generally small firms.

-Solar energy applications are required to classified as "essential service" as status.

-There are serious dismissals and discontinuities in the energy sector.

-To reduce the negative impact of the pandemic on the solar energy sector, governments need to perform the necessary incentives.

-The importance of "the energy transition process" has emerged once again and the use of such tools needs to be paved and procedures should be facilitated.

-Solar energy sector is predicted to recover in the second half of 2020.

-The federal tax credit is advised to be made refundable for the sector or payable directly to businesses and customers

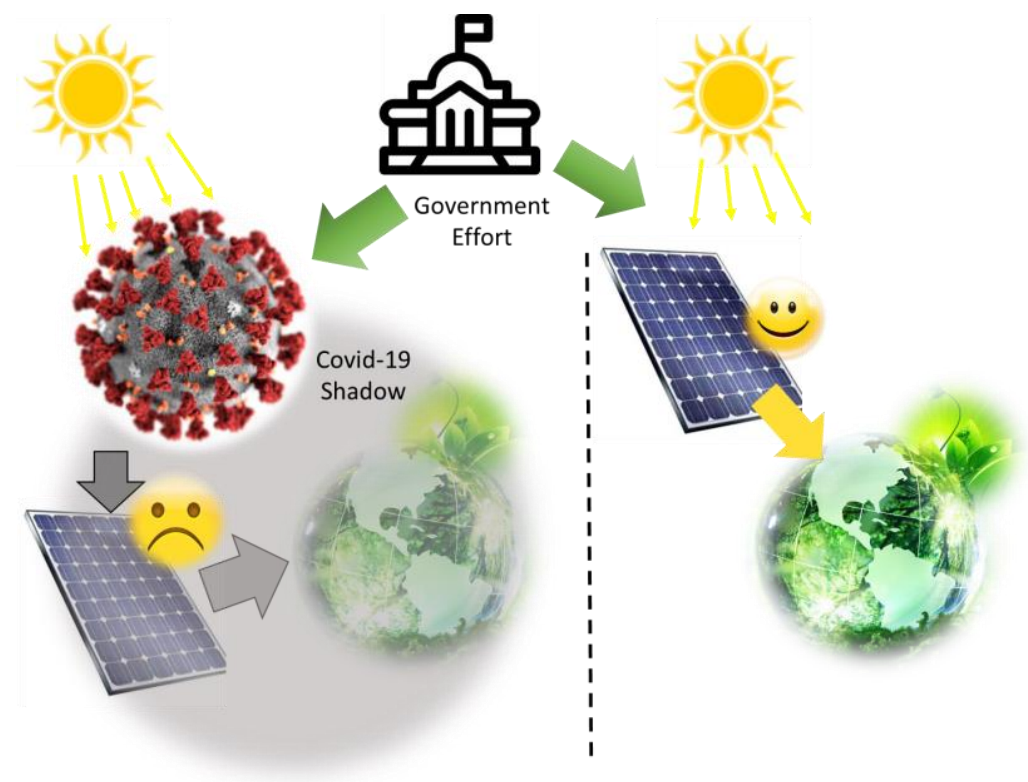

Figure 1. General illustration of the study. 


\section{SOLAR ENERGY SECTOR AND WEAKNESSES}

Solar energy is a sensitive sector which is tried to be kept alive with incentives [2,5,7,10] from past to present. The most obvious disadvantages of the sector can be listed as depending on daytime, low efficiency of solar panels, large space required for panel installation and high initial costs. In this sense, it is not difficult to assert that the sector is highly affected by global crises. The Covid-19 outbreak has forced governments to make strict sanctions, and this has caused notable restricts in people's social mobility $[5,11,12]$. The solar industry, which is very dependent on human interaction, has also been also directly affected by the pandemic. While the disruption of production in factories caused problems in the supply chain $[12,13,14,15]$, most solar panel applications such as roof type solar applications slowed down. The extent of the outbreak's impact on the industry $[16,17]$ is still being explored by researchers.

\section{RELATIONSHIP BETWEEN COVID-19 AND SOLAR ENERGY SECTOR}

The solar energy sector has covered a great distance from past to present. However, some unforeseen problems disrupt this rapid development trend. For example, the US subprime mortgage market collapsed in 2007, which also hit the solar energy industry [18]. The collapse negatively affected the prices of solar panels and other electronic equipment. The triggering of the fall in solar stock prices caused by the crisis made it difficult for manufacturing companies to sell more shares and collect more money. The situation of the sector at this point caused conflict among the ones who analysed the effects of the crisis on the solar energy sector. Some argue that the sector has been seriously injured while others claimed that there is not much shaking and there will be a recovery in the short term. Below are two different perspectives on the subject in two different titles.

\subsection{Findings Confirming that the Solar Sector is in a Negative Trend}

The main factor that caused the solar energy industry to be affected by the crises is that the main components of the solar sector are dependent on Chinese imports by 65-75\% [19]. Due to the outbreak in China, commercial exchanges between countries have been disrupted and this has affected solar sector exports [20]. According to a published report, global solar energy demand has been decreasing since 1980s [21]. Strict quarantine rules have also affected production activities, which caused an increase in material prices, although they have been expected to be temporary. Fig. 2 shows the change of PV module prices in different quarters of Covid-19 period on year basis. The prices estimated before the pandemic have increased significantly due to the Covid-19 outbreak. Although current material stocks did not cause a sharp increase in PV prices in the first quarter of 2020, it is estimated that it would increase to $0.27 \$ / \mathrm{W}$ in the second quarter $(\mathrm{Q} 2-2020)$ with the decrease in production. It is predicted that prices would approach the forecast values before covid-19 as the plants continue to operate in the third and fourth quarters [22].

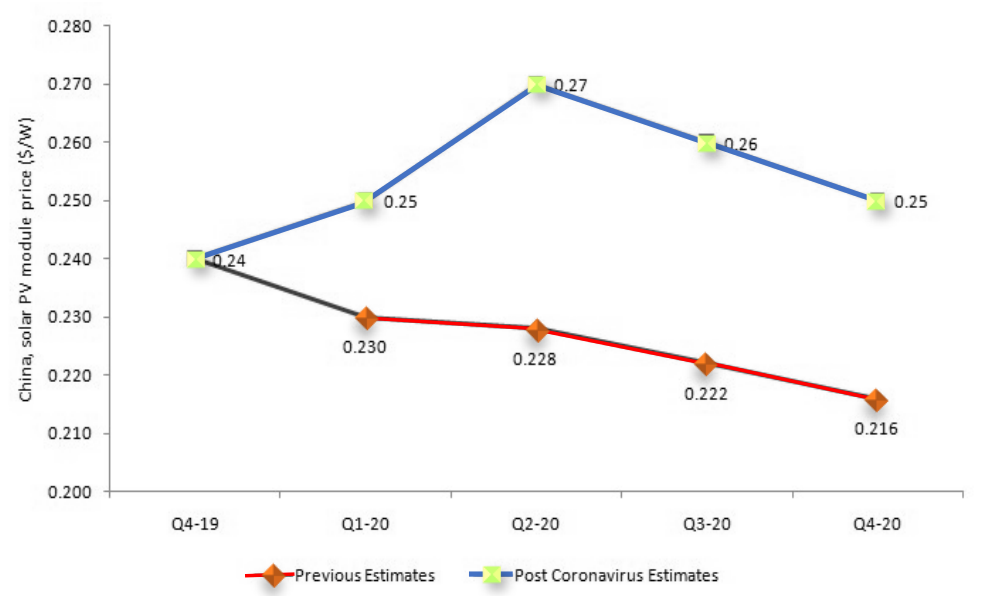

Figure 2. PV module prices throughout Covid-19 outbreak (Q1-20: First Quarter of 2020) [21,22]. 
On the other hand, the solar industry is mostly driven by installation, testing and commissioning efforts. Therefore, the technicians whose mobility is limited during the outbreak are unable to perform the installation stages [6]. Smaller companies that sell solar panels for roofs are the most affected ones in the industry [8]. It makes these companies difficult for customers to cancel or postpone orders to protect them from Covid-19 [8].

The US solar industry has had to lay off 65,000 people since the end of February due to Covid-19 outbreak [23]. The results of three surveys conducted by SEIA between 12 and 22 March 2020 are shown in Fig. 3. According to the survey data, the concern of the solar industry is shown in subjects such as availability of project debt, availability of tax equity, liquidity, construction delays, customer acquisition, customer credit, force majeure, interconnection delay, permitting delays and supply chain delays. The aforefold findings indicate that serious problems would likely to occur in the industry if the necessary measures are not taken $[8,24]$.

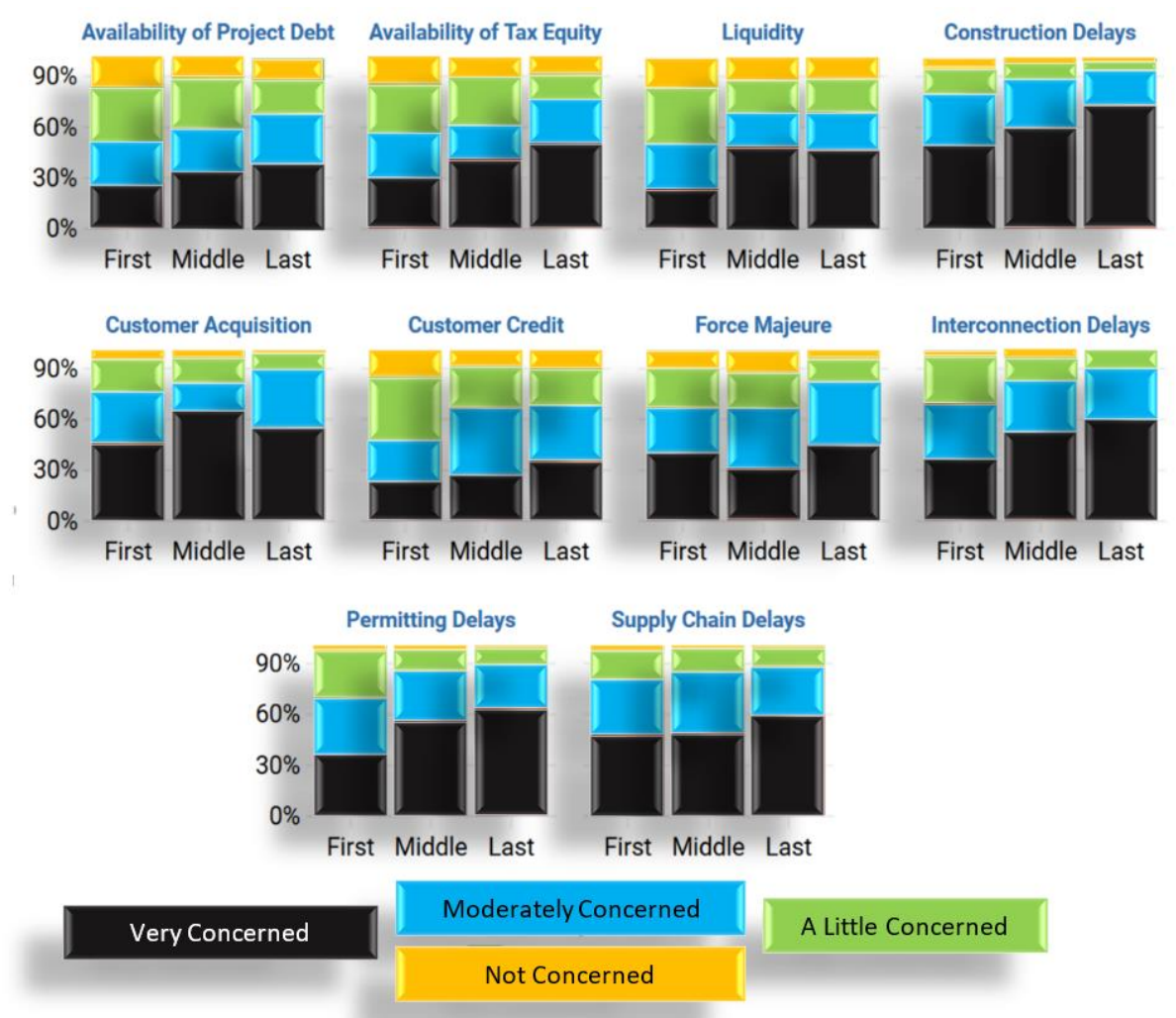

Figure 3. SEIA survey results on solar industry companies suffering from Covid-19 outbreak from Ref. [24].

Delay in the supply chain is another important problem of the industry [13, 28, 30]. It is revealed that there are serious problems regarding the supply of PV modules and necessary equipment due to the Covid-19 pandemic [21,26]. In line with all these evaluations, 2020 can be accepted as a "down year" for the first time since 1980s. In addition, projections proposed between 121-152 GW for 2020 have been revised as 108-143 GW with a decrease of $8 \%$ due to Covid-19 [28]. According to another prediction, 2020 solar energy estimates drop by $28 \%$ due to Covid-19 [2].

The situation in Europe is not very different. European representatives of the sector state that covid-19 is a global issue for the solar industry [7,9]. It is of vital importance to overcome this problem that "The energy transition process" is important and it is necessary to pave the way of using such tools, to facilitate permit procedures and to define temporary financial advantages. Environmental ministers from Austria, Denmark, Italy, Latvia, Luxembourg, the Netherlands, Portugal, Spain and Sweden have stated that the solar industry should be an important part of the incentive packages after Covid-19 and the European Green Deal policy framework is required to be monitored in economic recovery [5]. 


\subsection{Findings Confirming that the Solar Sector is in a Positive Trend}

It is also claimed by some sources that after the Covid-19 outbreak, there will be a positive acceleration in the solar industry [29]. Wang et al. revealed the positive effects of Covid-19 pandemic based on the positive data showing the positive progress of some companies [28]. Another reason behind this consensus is the positive recovery after the crisis in 2008 or the lesson obtained from the crisis. After 2008 , many solar energy manufacturers went bankrupt. However, the sector started to recover after 2008 and the price of polysilicon, which was $400 \$ / \mathrm{kg}$ in 2008, dropped to $20 \$ / \mathrm{kg}$ in 2013 [30].

Similarly, the decline in oil and gas prices a few years ago has increased the use of fossil fuels, which negatively affected the use of solar energy. In current circumstances, it is worrying that such a negative impact will trigger the fall in oil prices [7,12,31,32]. Oil prices during the pandemic is shown in Fig. 4. As seen in the Fig. 4, oil prices turned negative for the first time on Monday, April 21, 2020, due to Covid-19.

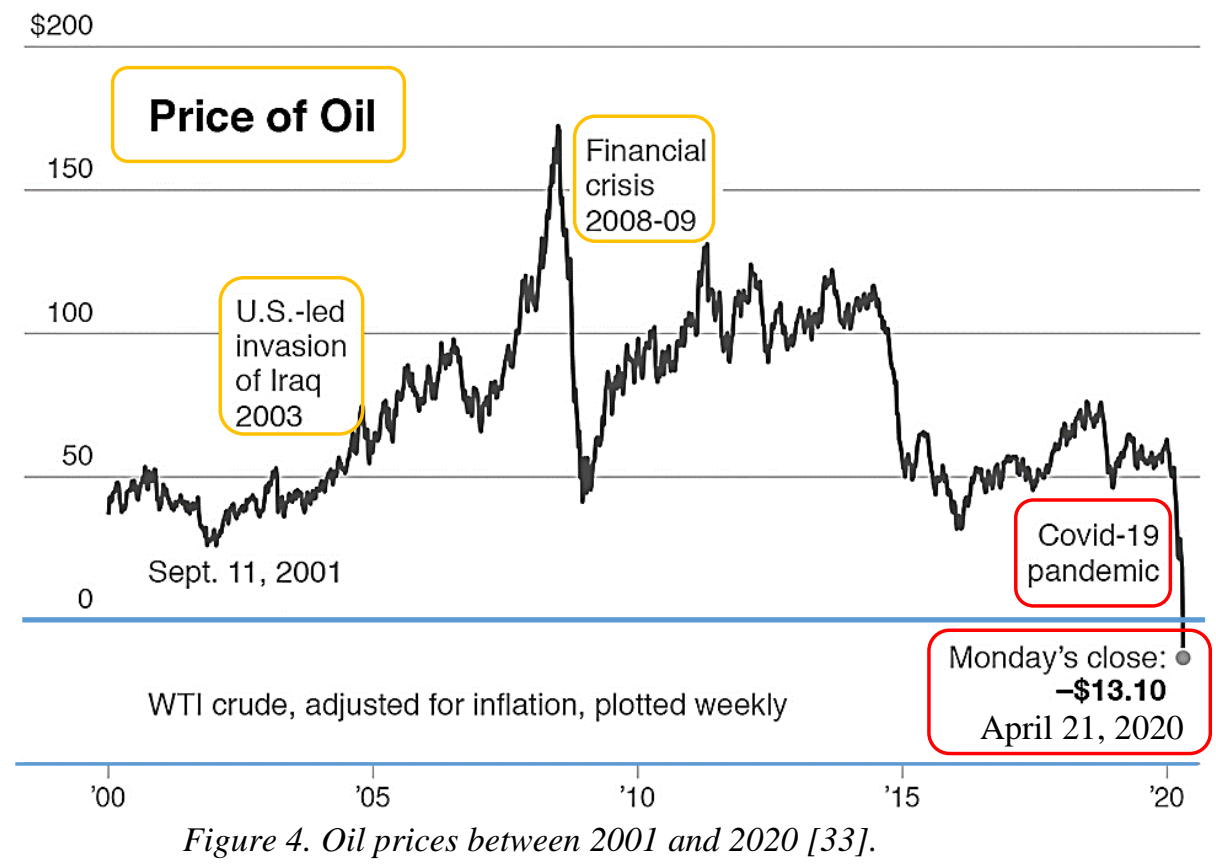

On the other hand, some data show that the trend may not be like this. It is reported that electricity produced from solar energy will be cheaper than all other technologies for new generation resources entering service in 2025 [34]. One reason for this is that the fall in oil prices did not affect natural gas and coal prices much during the Covid-19 outbreak. In this context, it is reported that the Covid-19 pandemic will cause changes in the market dynamics in favor of the solar industry. It is reported that despite the layoffs and disruptions in the sector, problems are not expected to continue in the long term and can be resolved in the short term [12].

Another positive effect of the pandemic in the solar energy sector is the increase in digital sales applications. Some sustainable energy development authorities are trying to raise awareness about solar energy by using different digital channels [8]. For this purpose, during the Covid-19 pandemic, companies have started to offer various software environments to offer their customers ease of planning, sales, and follow-up.

\subsection{What should be Done?}

Some important steps can be taken to help companies continue without the Covid-19 outbreak. The Solar Energy Industries Association, U.S. is trying to convince his congress for the use of the federal tax credit for the direct benefit of companies in distress in the industry [2]. Accordingly, 554 solar companies in the USA wrote a letter to the American congress expressing the problems of the sector 
[35]. In the letter, employees were asked to use the support provided by the congress for the solar industry employees. Another organization (GOGLA) is trying to reach an agreement with a group of investors to support solar energy companies with a fund of 100 million USD [36].

On the other hand, it is very important to classify solar applications as "essential service" as status. Some organizations called on governments to recognize off-grid solar as an "essential service". On the other hand, it would be useful to determine the correct type of support according to the company profile for the effective use of the supports planned [36].

In addition, investment tax credit usage, stretching credit payment dates, facilitating solar use permit procedures and increasing applications such as "Green Incentive" are also important steps in the rapid recovery of the sector [2]. In addition, studies should be carried out to analyse more detailed information on the progress of the sector and its sensitive points in measuring the effects of Covid-19 process.

\section{CONCLUSIONS}

The solar energy sector, which is one of the leading renewable and sustainable energy sources, has been seriously affected by the Covid-19 outbreak. Problems such as serious job losses in the sector, difficulties of companies in the short term, disruption or delay of jobs are the main problems faced by the sector. It is observed that relatively large firms can overcome problems in the short term. However, the same is not true for small companies. The dynamics of the sector, which are significantly dependent on human mobility, change with the effect of the pandemic. Planning, sales, and other operations can now be done in the industry using remote digital facilities. Also, considering the recovery of the sector in previous crises, the solar energy sector is expected to show a rapid recovery after the pandemic. In general, serious incentives and steps to ease the bottleneck are expected from governments in the sector. As a result, the sector, which has serious problems during the pandemic, can regain its old trend with the critical measures specified in this study.

\section{Acknowledgment}

The authors wish to thank all who assisted in conducting this work.

\section{REFERENCES}

[1] Klemeš, JJ, Fan, YV, Tan, RR, Jiang, P. Minimising the present and future plastic waste, energy and environmental footprints related to COVID-19. Renewable and Sustainable Energy Reviews 2020; 127: 1-8. DOI: $10.1016 /$ j.rser.2020.109883.

[2] Eroğlu, H. Effects of Covid-19 outbreak on environment and renewable energy sector. Environment, Development and Sustainability 2021; 23(4): 4782-4790. DOI: 10.1007/s10668-020-00837-4.

[3] Bera, B, Bhattacharjee, S, Shit, PK, Sengupta, N, Saha S. Significant impacts of COVID-19 lockdown on urban air pollution in Kolkata (India) and amelioration of environmental health. Environment, Development and Sustainability 2020; 23(5): 6913-6940. DOI: 10.1007/s10668-020-00898-5.

[4] Patrício, Silva AL, Prata, JC, Walker, TR, Duarte, AC, Ouyang, W, Barcelò, D, et al. Increased plastic pollution due to COVID-19 pandemic: Challenges and recommendations. Chemical Engineering Journal 2021; 405: 126683. DOI: $10.1016 /$ j.cej.2020.126683.

[5] Tsai, WT. Impact of COVID-19 on energy use patterns and renewable energy development in Taiwan. Energy Sources, Part A: Recovery, Utilization and Environmental Effects 2021. DOI: 10.1080/15567036.2021.1896611.

[6] Das, K. Impact of COVID-19 Pandemic Into Solar Energy Generation Sector. SSRN Electronic Journal 2020. DOI: $10.2139 /$ ssrn.3580341.

[7] Halbrügge, S, Schott, P, Weibelzahl, M, Buhl, HU, Fridgen, G, Schöpf M. How did the German and other European electricity systems react to the COVID-19 pandemic? Applied Energy 2021; 285: 116370. DOI: 10.1016/j.apenergy.2020.116370. 
[8] Vaka, M, Walvekar, R, Rasheed, AK, Khalid, M. A review on Malaysia's solar energy pathway towards carbon-neutral Malaysia beyond Covid'19 pandemic. Journal of Cleaner Production 2020; 273: 122834. DOI: 10.1016/j.jclepro.2020.122834.

[9] Gillingham, KT, Knittel, CR, Li, J, Ovaere, M, Reguant, M. The Short-run and Long-run Effects of Covid-19 on Energy and the Environment. Joule 2020; 4(7): 1337-1341. DOI: 10.1016/j.joule.2020.06.010.

[10] Pranadi, AD, Setiawan, EA, Pranadi, AD, Setiawan EA. Cost benefit analysis for peer-to-peer mechanism in residential sector of a single buyer electricity market. Journal of Energy Systems 2020; 4(4): 179-195. DOI: $10.30521 /$ jes.748138.

[11] Naderipour, A, Abdul-Malek, Z, Ahmad, NA, Kamyab, H, Ashokkumar, V, Ngamcharussrivichai, C, et al. Effect of COVID-19 virus on reducing GHG emission and increasing energy generated by renewable energy sources: A brief study in Malaysian context. Environmental Technology and Innovation 2020; 20: 1-8. DOI: 10.1016/j.eti.2020.101151.

[12] Chiaramonti, D, Maniatis, K. Security of supply, strategic storage and Covid19: Which lessons learnt for renewable and recycled carbon fuels, and their future role in decarbonizing transport? Applied Energy 2020; 271: 1-10. DOI: 10.1016/j.apenergy.2020.115216.

[13] Khan, S, Haleem, A, Deshmukh, SG, Javaid, M. Exploring the Impact of COVID-19 Pandemic on Medical Supply Chain Disruption. Journal of Industrial Integration and Management 2021; 4(2): 235-255. DOI: 10.1142/s2424862221500147.

[14] Patel, P, Gohil, P. Role of additive manufacturing in medical application COVID-19 scenario: India case study. Journal of Manufacturing Systems 2021, 60(2021) 811-822. DOI: 10.1016/j.jmsy.2020.11.006.

[15] Tokazhanov, G, Tleuken, A, Guney, M, Turkyilmaz, A, Karaca, F. How is COVID-19 experience transforming sustainability requirements of residential buildings? A review. Sustainability 2020; 12(20): 120. DOI: $10.3390 /$ su12208732.

[16] Javaid, M, Haleem, A, Vaishy,a R, Bahl, S, Suman, R, Vaish, A. Industry 4.0 technologies and their applications in fighting COVID-19 pandemic. Diabetes and Metabolic Syndrome: Clinical Research and Reviews 2020; 14(4): 419-422. DOI: 10.1016/j.dsx.2020.04.032.

[17] Ito, H, Hanaoka, S, Kawasaki, T. The cruise industry and the COVID-19 outbreak. Transportation Research Interdisciplinary Perspectives 2020; 5: 1-8. DOI: 10.1016/j.trip.2020.100136.

[18] Chase J. Solar After the 2008 Crash: Finding a New Normal. In: Jenny C, editors. Solar Power Finance Without the Jargon. BloombergNEF, Switzerland: World Scientific, 2019. pp. 79-84.

[19] Rabe, W, Kostka, G, Smith, SK. China's supply of critical raw materials: Risks for Europe's solar and wind industries? Energy Policy 2017; 101: 692-699. DOI: 10.1016/j.enpol.2016.09.019.

[20] Sandor, D, Fulton, S, Engel-Cox, J, Peck, C, Peterson, S. System dynamics of polysilicon for solar photovoltaics: A framework for investigating the energy security of renewable energy supply chains. Sustainability 2018; 10(1): 160. DOI: 10.3390/su10010160.

[21] Tiansen, YS, Yin, L, Ye, L, Bin. The influence of COVID-19 on grid parity of China's photovoltaic industry. Environmental Geochemistry and Health 2021;1-16. DOI: 10.1007/s10653-020-00701-4.

[22] Radu A, Panaite CE, Popescu A. Impact of COVID-19 pandemic on renewable sources implementation: Case of PV systems in Romania. In: IOP Conference Series: Materials Science and Engineering; 16-17 September 2020: IOP Publishing, pp. 1-9.

[23] Internet Web-Site: https://www.seia.org/news/covid-19-erases-five-years-solar-job-growth, Lyons, M. COVID-19 Erases Five Years of Solar Job Growth; SEIA 2021, 24 May 2021.

[24] Internet Web-Site: https://www.seia.org/blog/survey-findings-things-are-bad-and-getting-worse, Hopper, AR. Survey Findings: Things are bad and getting worse; SEIA, 4 June 2020.

[25] Birol, F. Put clean energy at the heart of stimulus plans to counter the coronavirus crisis - Analysis - IEA. Iea 2020: $1-4$.

[26] Sandor, D, Fulton, S, Engel-Cox, J, Peck, C, Peterson, S. System dynamics of polysilicon for solar photovoltaics: A framework for investigating the energy security of renewable energy supply chains. Sustainability 2018; 10(1):160. DOI: 10.3390/su10010160.

[27] Song,Y, Liu, T, Li, Y, Ye, B. The influence of COVID-19 on grid parity of China's photovoltaic industry. Environmental Geochemistry and Health 2021; 1-16. DOI: 10.1007/s10653-020-00701-4.

[28] Wang, QJ, Chen, D, Chang, CP. The impact of COVID-19 on stock prices of solar enterprises: A comprehensive evidence based on the government response and confirmed cases. International Journal of Green Energy 2021; 18(5): 443-456. DOI: 10.1080/15435075.2020.1865367.

[29] Czech, K, Wielechowski, M. Is the Alternative Energy Sector COVID-19 Resistant? Comparison with the Conventional Energy Sector: Markov-Switching Model Analysis of Stock Market Indices of Energy Companies. Energies 2021; 14(4): 1-17. DOI: 10.3390/en14040988.

[30] Chase J. Solar power finance without the jargon. BloombergNEF, Switzerland: World Scientific, 2019. 
[31] Munawar, HS, Khan, SI, Qadir, Z, Kouzani, AZ, Mahmud MAP. Insight into the impact of COVID-19 on Australian transportation sector: An economic and community-based perspective. Sustainability 2021; 13(3): 1-24. DOI: 10.3390/su13031276.

[32] Hawash, B, Abuzawayda, YI, Mokhtar, UA, Yusof, ZM, Mukred, M. Digital Transformation in the Oil and Gas Sector during Covid-19 Pandemic. International Journal of Management 2020; 11(12): 717-724. DOI: 10.34218/IJM.11.12.2020.067.

[33] Alqahtani, A, Selmi, R, Hongbing, O. The financial impacts of jump processes in the crude oil price: Evidence from G20 countries in the pre- and post-COVID-19. Resour Policy 2021; 72:1-16. DOI: 10.1016/J.RESOURPOL.2021.102075.

[34] Burnett, JW, Hefner, F. Solar energy adoption: A case study of South Carolina. The Electricity Journal 2021; 34(5): 106958. DOI: 10.1016/j.tej.2021.106958.

[35] Internet Web-Site: https://www.seia.org/news/more-550-solar-companies-tell-congress-protect-250000americans-solar-industry, Lyons, M. More than 550 Solar Companies Tell Congress to Protect the 250,000 Americans in the Solar Industry | SEIA 2020, 5 May 2021

[36] Internet Web-Site: https://www.gogla.org/about-us/blogs/covid-19-how-gogla-is-helping-the-off-grid-solarindustry-deal-with-the-crisis, Peters, K. COVID-19: How GOGLA is helping the off-grid solar industry deal with the crisis; 5 May 2021. 